THE LIBERAL HERESY 


\section{THE LIBERAL HERESY}

Origins and Historical Development

MASSIMO SALVADORI

Macmillan Education 
ISBN 978-0-333-21681-1 ISBN 978-1-349-15825-6 (eBook)

DOI 10.1007/978-1-349-15825-6

(C) Massimo Salvadori 1977

Softcover reprint of the hardcover 1st edition 1977 978-0-333-21680-4

All rights reserved. For information, write:

St. Martin's Press, Inc., 175 Fifth Avenue, New York, N.Y. 10010

Library of Congress Catalog Card Number: 77-82859

ISBN: 978-0-312-48250-3

First published in the United States of America in 1977 


\section{CONTENTS}

Foreword $\quad$ xi

An heretical experience $\quad$ xi

The theme xii

Apologies xiv

Introduction 1

Aim of the book $\quad 1$

Random references to political liberalism today 4

A declining but still influential 'ism' 5

Expanding radical authoritarianism $\quad 8$

$\begin{array}{ll}\text { Three points concerning approach } & 9\end{array}$

(a) Method $\quad 9$

(b) Inner convictions versus outer conditions 10

(c) Causation 11

Liberalism and liberty's essential role $\quad 12$

The birthplace of liberalism $\quad 13$

1. Liberalism: a Definition 16

An 'ism' is ideas and institutions 16

A wide range of meanings $\quad 17$

The search for the common denominator 19

The evidence provided by acting together in a movement 20

A social order founded on individual autonomy 22

Liberty $\quad 22$

The problem of diversity 24

Liberalism as equal liberty $\quad 25$

Four other key elements $\quad 26$

(a) Reasonableness $\quad 27$

(b) The dignity of the individual 27

(c) Moral equality $\quad 28$

(d) Tolerance $\quad 29$

Liberty for non-liberals $\quad 29$

The optimum is not the maximum 30 
Liberalism and anarchism

Centrifugal pull: moderatism and progressivism $\quad 33$

Frontiers of liberalism $\quad 34$

2. Liberal Institutions 36

Priority of the political $\quad 36$

Self-government $\quad 37$

Suffrage $\quad 38$

Liberal constitutionalism $\quad 39$

Fear of the mob and 'bourgeois' democracy 40

The priority of inalienable rights over the will of the
majority

Liberal democracy $\quad 43$

The rule of law $\quad 45$

The rule of law benefits all $\quad 46$

Liberalism is not permissiveness $\quad 46$

Liberalism shifts the source of power from above to below 47

Unchanging method to achieve ever-changing goals 48

$\begin{array}{ll}\text { National sovereignty } & 49\end{array}$

Institutional pillars $\quad 50$

Liberal concern with education $\quad 51$

Repressiveness of most educational systems $\quad 52$

Liberal 'new education' 53

Property $\quad 54$

Free enterprise $\quad 55$

Beyond the economic optimum $\quad 56$

Liberals' reformed free enterprise $\quad 58$

The welfare economy $\quad 59$

3. A Long and Difficult Journey 60

$\begin{array}{ll}\text { Liberty as burden } & 60\end{array}$

Authoritarian orthodoxy and liberal heresy 61

$\begin{array}{ll}\text { The awareness of reason } & 62\end{array}$

The beginning of philosophy, history and science 63

Law and Romans 64

Law divorced from religion $\quad 65$

$\begin{array}{ll}\text { A unique religion } & 67\end{array}$

The nominalistic heresy $\quad 68$

The dignity of man $\quad 69$

A radical revolution $\quad 70$

Facing God $\quad 71$

$\begin{array}{ll}\text { The emancipation of minds } & 72\end{array}$

$\begin{array}{ll}\text { Progressivism and obscurantism } & 73\end{array}$

$\begin{array}{ll}\text { The advance of science } & 74\end{array}$ 
Freedom of expression

Fortuitous success of liberalism's political forebears $\quad 76$

$\begin{array}{ll}\text { The greatest heresy, tolerance } & 77\end{array}$

$\begin{array}{ll}\text { Seven major steps } & 79\end{array}$

4. The Liberal Era: (i) Where English is Spoken 80

A common source for English-speaking nations 80

The Whig century in Great Britain $\quad 81$

Whiggism: an attitude and a programme $\quad 82$

Dynamism and achievements belonging to citizens, not to the state

Growing differentiation

The Liberal century in Great Britain $\quad 86$

The Liberal state advantages all, not Liberals only $\quad 87$

The ethical core of the Liberal century $\quad 89$

Towards equality within liberty $\quad 90$

From an empire to a commonwealth $\quad 92$

Liberalism with a small ' $\mathrm{l}$ ' survives Liberalism with a capital ' $\mathrm{L}$ '

West and East: beyond Whiggism 94

Towards 1776: meeting houses and stockades instead of palaces, cathedrals and fortresses

1776 and 1787 : liberal constitutionalism 95

The parting of the ways: moderatism and progressivism $\quad 97$

American liberalism $\quad 98$

Liberal democracy strongly entrenched $\quad 99$

Variety makes for richness of life 101

$\begin{array}{ll}\text { Concrete problems } & 102\end{array}$

Regulation of free enterprise 103

In the black 104

The main failure 106

$\begin{array}{ll}\text { Some successes } & 107\end{array}$

Liberalism in other English-speaking nations and communities

English-speaking nations and communities in which liberalism has failed

5. The Liberal Era: (ii) Continental Europe 115

The Continent 115

Continental liberalism $\quad 116$

The eighteenth century: prelude to the liberal era 118

$\begin{array}{ll}\text { The authoritarian road to progress } & 119\end{array}$

The anti-authoritarian road 120

1789 
The intelligentsia comes into its own $\quad 122$

The radicals' revolt against liberalism 124

Jacobins 125

An old ideology in modern clothing 127

Jacobinism as the source of twentieth-century totalitarianism

In the wake of 1789

Post-Napoleonic course of continental liberalism $\quad 131$

Continental liberals as an influential minority 133

The political realignment of the 1870 s 133

Towards liberal democracy 134

The sin of pride $\quad 135$

Sins of greed and fury $\quad 137$

The sin of arrogance 139

Liberal decline after the First World War 141

Short-lived freedom in 'successor' states 142

West of 'successor' states 144

On the road to liberal socialism 148

Lay and confessional conservatism veer towards liberal moderatism 151

Elements of weakness $\quad 152$

6. Liberalism in Latin America, Eastern Civilisations and the Arabian/African Region $\quad 154$

Latin America: independence with little liberty 154

Oligarchia $\quad 155$

Slow beginning of emancipation $\quad 157$

$\begin{array}{ll}\text { Onward } & 158\end{array}$

Backward 159

'Oriental despotism' in eastern civilisations 162

Russia's closed society 163

The Russian 'thaw' of the 1860s 164

1917: the tragic failure of liberalism 165

Turkish progressivism 167

The 'closed' continent closes again 169

Japan: a question mark for liberals $\quad 172$

Indians try liberal democracy 174

The other Indies in the East 177

From the Euphrates to the Orange River: independence $\begin{array}{ll}\text { and dictatorship } & 178\end{array}$

7. Success brings Failure 183

The impact of liberalism $\quad 183$

$\begin{array}{ll}\text { The liberals' democracy } & 184\end{array}$ 
Liberals suppress slavery $\quad 185$

Escape from despotism $\quad 186$

The breaching of the intellectual dyke $\quad 187$

The breaching of economic dykes 189

$\begin{array}{ll}\text { Towards equality } & 191\end{array}$

Emancipation of half the population 194

Humanitarianism 195

The independence of nations $\quad 197$

Internationalism 199

Pluses 200

Adverse effects of the release of energies 201

Flooding the earth 203

Responsibility: a burden for many 204

The mote and the beam 205

Liberalism's Achilles' heel 206

8. Conclusion 210

Purgatory 210

Guidance versus spontaneity 211

Liberals' and socialists' mutual ambivalence $\quad 212$

Liberty erodes conservatism $\quad 216$

'Making overmuch of liberty' 217

49 B.C., A.D. $1434, \ldots$ ? $\quad 218$

Bibliographical note $\quad 220$

Selective index-glossary 230 


\section{To Joyce}

to whom I owe more than I can say

this book is dedicated 


\section{FOREWORD}

\section{AN HERETICAL EXPERIENCE}

A civilisation was born in modern times in the midst of turmoil and suffering. Its beginnings were modest. Although resented by most people much of the time nearly everywhere, for a few generations it affected all mankind, and transformed most of it. Now, in the midst of greater turmoil and of tensions unendurable for many, limited to a small minority of independent states belonging primarily to the First World, passionately attacked at all levels from all sides, it is losing ground; this is why the book has been written.

The autonomy and responsibility of individuals, and the choices they made, were central to the civilisation: not the rights of society and the state, not guidance by rulers who know what is good for everybody. With power deriving from the freely expressed and everchanging will of the citizens, the relationship between people and state was reversed institutionally. Contrary to what happened everywhere in the past, and happens today in Second and Third World civilisations and in illiberal states of the First, goals and policies mattered less than the way goals were pursued and decisions about policies taken.

A radical departure from the age-old orthodoxy of authoritarian and conformist societies (nearly as dominant in the world today as it once was), this civilisation has been heretical both at the level of ideas and of institutions - of spiritual and practical activities. It reduced repression, and in consequence there came expansion and advancement in all fields of endeavour. This was the credit side. Minds and expression being freer than ever before, awareness of remaining repression increased, bringing unhappiness; action being freer, tensions increased. This was the debit side.

The driving force of the new civilisation was a striving for libertyfor the right and duty to be not just a unit in the herd but oneself. It took a long time to clarify the ideas implicit in the striving, and to decide through what institutions the ideas could become a way of life. A long period elapsed before clear ideas were held by enough 
people to become a political force. Once they did, they gave direction to a movement which, successful in the revolutions of 1688 , 1776 and 1789, established the institutional structure later described as 'liberal'.

\section{THE THEME}

This book deals with the movement leading to the three revolutions, and to many kindred ones in all continents - some successful for long or short periods, others not - which occurred from the 1790s to the 1970s. Early revolutionaries summed up their position in the British Bill of Rights, the French Declaration of Rights, the American Ten Amendments, in statutes substituting for constitutions and in written constitutions, and in slogans such as the 'free and equal' of the second revolution, 'liberty, equality, fraternity' of the third. Liberalism is the movement of those who drafted Bill, Declaration and Amendments, who approved statutes and constitutions, who used the slogans, who replaced servile institutions with free institutions. What they had in common mattered more in humanity's historical scheme than what divided them. Today, conflicts between advocates and opponents of free institutions are what matter, not dissensions between progressive and moderate advocates of the same institutions, or antagonisms between different factions of opponents.

The goal of the forerunners of liberalism, and of liberals since the term came into use in its ideological-political meaning, was emancipation: immediate emancipation of minds from dogmas and superstitions, and of citizens from despotism. In time, liberals hoped, there would result emancipation from disease, ignorance, poverty, discrimination and war. Emancipation meant an institutional structure within which people would decide what direction to move in, if they wanted to move. It meant means to achieve ends, not specific ends. The institutional structure has been known as 'liberal constitutional', if suffrage was limited, 'liberal democratic' if suffrage was universal. (Inappropriately because of the varied meanings of democracy, many, particularly in North America, call the institutional structure democratic tout court. Unswervingly centred on liberty, Scandinavian-type social democracy, enriched with institutions promoting justice, belongs to the liberal family.)

The original liberties were freedom of expression (worshipping openly according to one's conscience, saying and printing what one wanted) and political freedom (the free election of those who make laws and supervise their application), both being meaningful when 
several requirements are fulfilled. These two and none other are liberalism's essential liberties; these and none other provide the criterion distinguishing a free society from an authoritarian one. Important, but not essential on the basis of long-standing evidence, is economic liberty, correctly understood as institutions facilitating changes in economic structures, including the passage from one economic system to another (and not to be identified, as is mistakenly done by many, with capitalism, a by-product in continual transformation of the drive for emancipation, now largely replaced by mixed welfare economies). The two essential liberties interest all and have no sectional, or class, connotation.

Within the relative security of liberal constitutional and, more recently, liberal democratic states, emancipation expressed itself in new ideas, aspirations and movements. Some strengthened the institutional structure and improved it, others aimed at destroying it. Different from the traditional authoritarian forces against which liberals had struggled, new enemies of liberty ranged from dictatorial sectors of radical revolutionarism at the end of the eighteenth century, to dictatorial sectors of today's liberation movements which would play a liberal role if to the pursuit of specific goals of emancipation they did not add the obliteration of freedom of expression and of political liberty, and of everything making them meaningful.

One set of enemies nearly won in the early 1940s. They were held together by frenzied nationalistic conviction of their own superiority. Another set of enemies is gaining ground in all continents today. Its unifying element is hatred of capitalism - for most of its opponents a vague term covering everything they are against. Their hatred is reinforced by the conviction that they are agents of laws immanent in society, the laws in turn justifying any action one engages in. This hatred is more and more an obsession in ever-widening circles of the intelligentsia, the dynamic minority now guiding mankind. What was essential in emancipation - freedom of the mind to explore and blaze new trails, to create and to invent, freedom to share one's convictions with others, institutions centred on self-government to guarantee these freedoms, respect for others, legitimacy of opposition and dissent - is all dismissed as futile, harmful, or a dream. To eliminate malignant economic growths, the whole liberaldemocratic structure and the ideas and values on which it rests, are to be eliminated. Once liberty of the mind and political liberty are lost, they may remain lost - forever. Mankind may revert in its entirety to the authoritarianism and conformity of the pre-liberal past. Whatever the wave of the future may be, it behoves one to be aware of what the liberal heresy is, and how it came about. 


\section{APOLOGIES}

In other times, the title of this book might have been: 'An Introduction to the Study of Liberalism, its Nature, and its Historical Development in Modern Times as an Ideological-Political Force'. This is what the book is. As an introduction, it is necessarily incomplete; by synthesising it contains the margin of error unavoidable in all generalisations and simplifications; as a history it can be no more than a survey. On the three counts it falls short of scientific precision. In justification, it can be said that a subject alien to the consciousness of many requires an introduction and that, didactically, synthesis and survey precede analysis and detailed study of specific developments.

The index-glossary (page 230) provides brief definitions of terms to which various meanings are attached (e.g. 'imperialism') or which are not in common use (e.g. 'centrist socialism'). The use of capitals has been restricted; in some cases it is self-explanatory ('Continent', for instance, is the European continental area of Western civilisation, and 'Liberal party' is a specific party of that name). There are many names of individuals, largely in order to compensate for the often misleading simplification of general terms: the impersonal Free Democrats, for instance, does not give the idea of inner tensions, outer pressures, complexity of positions and problems personified in Heuss or Scheel. Footnotes have been dispensed with, as academically pretentious in an introductory survey.

There are a few more points. In this book, liberalism is seen in the context of global developments, not just Western ones; this changes the perspective. What among five or six hundred million Westerners is obvious and 'natural' is neither obvious nor natural among the world's four thousand millions. In the second place, while books on ideological-political positions called 'isms' mainly deal with goals, programmes and policies, a book on liberalism deals primarily with what makes goals, programmes and policies possible - that is to say with the basic institutional structure. Thirdly, little reference is made here to the economic side of liberalism or other 'isms'. This is not because of lack of awareness of economic problems and of the obsessive interest in them (this writer's doctoral thesis and much of his subsequent writing has been in the field of political economy) but because the role of economics matters less than the role of ideas (for instance, not an economic problem per se moves people to action, but the idea they have of the problem) and of politics, or management of society's institutional structure. Finally, as the mind is an imperfect (albeit marvellous) instrument and all faculties are limited, 
any phenomenon - in this book, liberalism - is perceived somewhat incorrectly; what one can, and should do, is to be as correct as

possible - and to stress, unequivocably and everywhere, the freedom of thought and of expression which only can reduce inaccuracies.

San Tommaso, Capodarco, Italy

March 1977 